Ambiente \& Água - An Interdisciplinary Journal of Applied Science
ISSN 1980-993X - doi:10.4136/1980-993X
www.ambi-agua.net
E-mail: ambi-agua@agro.unitau.br

\title{
Hydrogeochemical attributes and ground water quality of Ngbo Community in Ohaukwu Area Council, Ebonyi State, Nigeria
}

\author{
doi: 10.4136/ambi-agua.1453 \\ Received: 03 Jul. 2014; Accepted: 29 Oct. 2014 \\ Omaka Ndukaku Omaka ${ }^{1}$; Ifeanyi Francis Offor ${ }^{1 *}$; \\ Ikechukwu Moses Onwe ${ }^{2}$ \\ ${ }^{1}$ Federal University, Ndufu Alike, Ikwo, Abakaliki, Ebonyi State, Nigeria
Department of chemistry
${ }^{2}$ Federal University, Ndufu Alike, Ikwo, Abakaliki, Ebonyi State, Nigeria
Department of Geology
${ }^{*}$ Corresponding author: e-mail: offorifeanyi@ gmail.com,
omaka.nduka@gmail.com, ikechukwumoses@ymail.com
}

\section{ABSTRACT}

This study evaluated the hydrogeochemical attributes and quality of groundwater resources in Ngbo, Ohaukwu Area Council of Ebonyi State, Nigeria in order to determine whether boreholes in the area were suitable for potable uses. Eleven groundwater samples were collected from hand-dug boreholes between February and March, 2013. The physiochemical parameters of the samples were then analyzed to determine electrical conductivity, total dissolved solids, total alkalinity, major cations and anions, and trace metals. The quality of these characteristics was evaluated by comparing them to the Nigerian Institute of Standards, the Bureau of Indian Standards and the World Health Organization standards for drinking water quality. Mass abundance of the major ions was in the order of $\mathrm{Mg}^{2+}>\mathrm{Ca}^{2+}$ for cations, $\mathrm{Cl}^{-}>\mathrm{SO}_{4}{ }^{2-}>\mathrm{NO}_{3}{ }^{-}>\mathrm{PO}_{4}{ }^{3-}$ for anions and $\mathrm{Fe}>\mathrm{As}>\mathrm{Mn}>\mathrm{Cu}>\mathrm{Zn}$ $>\mathrm{Cr}>\mathrm{Ni}>\mathrm{Pb}>\mathrm{Cd}$ for trace metals. Correlation analysis revealed both positive and negative correlations among the parameters. Also, one-way ANOVA tests revealed that no significant differences existed between physiochemical parameters $(F=1.004<$ Fcrit $=1.977)$, major cations and anions $(\mathrm{F}=0.547<\mathrm{Fcrit}=2.008)$ and trace metals $(\mathrm{F}=0.772<$ Fcrit $=1.940)$ regardless of the sampling location. Groundwater in the area was generally hard, alkaline and highly mineralized, making it unsuitable for drinking in some places due to high total hardness and TDS; but it was generally suitable for irrigation purposes. It is recommended that boreholes be flushed regularly to aid in the removal of mineralized deposits, and that regular hydrogeochemical studies be conducted in order to detect future deterioration of water quality.

Keywords: borehole, hydrogeochemistry, water quality.

\section{Atributos hydrogeoquímicos e qualidade das águas subterrâneas da Comunidade Ngbo de Ohaukwu, Estado de Ebonyi, Nigéria}

\section{RESUMO}

As investigações sobre os atributos hydrogeoquímicos e a qualidade das águas subterrâneas da Comunidade Ngbo no Conselho de Área Ohaukwu, Estado de Ebonyi, 
Nigéria foram realizadas para avaliar a adequação dos poços para água potável. O estudo envolveu onze amostras de água subterrânea coletadas em poços cavados a mão entre Fevereiro e Março de 2013. Parâmetros físico-químicos incluindo condutividade elétrica, sólidos dissolvidos totais, alcalinidade total, os principais cátions e ânions superóxidos e metais foram analisados em amostras de água subterrânea e suas características de qualidade avaliadas e comparadas com o padrão do Nigerian Institute of Standards, do Bureau of Indian Standards e com o World Health Organization Standards para o consumo de água. A ocorrência dos principais íons apresentou a seguinte ordem: $\mathrm{Mg}^{2+}>\mathrm{Ca}^{2+}$ para os cátions, $\mathrm{Cl}^{-}$ $>\mathrm{SO}_{4}{ }^{2-}>\mathrm{NO}_{3}{ }^{-}>\mathrm{PO}_{4}{ }^{3-}$ para os ânions e $\mathrm{Fe}>\mathrm{Mn}>\mathrm{Cu}>\mathrm{Zn}>\mathrm{Cr}>\mathrm{Ni}>\mathrm{Pb}>\mathrm{Cd}$ para os metais traços. A análise correlações positivas e negativas entre os parâmetros. Além disso, testes de ANOVA revelaram que não houve diferença significativa $(\mathrm{F}=1,004<\mathrm{Fcrit}=$ 1.977) entre os parâmetros físico-químicos, e entre os principais cátions e ânions $(\mathrm{F}=0,547<$ Fcrit $=2.008)$, assim como entre os elementos traços $(\mathrm{F}=0,772<$ Fcrit $=1.940)$ independentemente do local de amostragem. As águas subterrâneas na área eram de modo geral duras, alcalinas e altamente mineralizadas, portanto, impróprias para consumo em alguns lugares devido à alta dureza total e TDS, mas geralmente adequadas para irrigação. Lavagens regulares dos poços para auxiliar a remoção de minerais depositados e estudos hidrogeoquímicos regulares são importantes para a detecção de deterioração da qualidade da água no futuro.

Palavras-chave: hidrogeoquímica, poço artesiano, qualidade da água.

\section{INTRODUCTION}

Water is vital to man's existence and without it there would be no life on earth. It has numerous applications ranging from domestic applications such as drinking, cooking, washing and bathing to agricultural and industrial applications such as irrigation, power generation and industrial production. The earth holds approximately $1.4 \times 10^{9}$ cubic kilometers of water in the form of oceans, seas, rivers, lakes, ice, etc.; but only $3 \%$ of the total available water resources are in the form of fresh water found in rivers, lakes and groundwater. The fresh water that is needed for a clean water supply is limited, and demand far exceeds the available supply due to increasing population and industrialization (APHA et al., 2012).

Recently, the need to determine the quality of public water supply has been intensified as a result of an increase in water pollution on a global scale caused by increasing population, urbanization and industrialization (Achi, 2003; Olatunji et al., 2005; Nwankwoala et al., 2007; Amadi et al., 2012).

A clean water supply is one of the key indicators for development in any country; however, the situation of most African countries is not encouraging. For instance, eighteen African countries are expected to experience a water shortage by 2025, and there are currently more than 300 million people in Africa living in water scarce environments (Abam, 2001). In Sub-Saharan Africa, the water requirements for major domestic and industrial purposes are usually not met. The available water resources continue to dwindle, and the amount of freshwater available for each person in Africa is about one-quarter of what it was in 1950 (Abam, 2001).

Nigeria as a nation is blessed with abundant surface and groundwater resources, especially in south-southern, south-eastern and south-western regions of the country (Obatoyinbo and Oyedotun, 2011).

According to Rijswijk (1981), groundwater found between a $0-50 \mathrm{~m}$ depth in Nigeria is estimated to cover about $6 \times 10^{6} \mathrm{~km}^{3}$, while using the eight mega regional aquifiers in 
Nigeria to estimate the country's total ground water yielded 50 million trillion liters per year (Akujieze et al., 2003). On the other hand, surface water resources in Nigeria are estimated at 224 trillion liters per year (Hanidu, 1990).

As far back as the 1980s, when the international drinking water supply and sanitation decade (1980-1990) was declared, Nigeria had already launched a national borehole program which proposed water for all by the year 2000. About 760 boreholes were earmarked for the program; but only 228 were actually installed, thus leading to a failure of the project (Akujieze, 2003; NPC, 2006).

Due to increasing cases of water pollution associated with surface waters, more attention has been shifted to groundwater sources, leading to an increase in well and borehole digging in both rural and urban centers in Nigeria (Oyedotun and Obatoyinbo, 2012). Several factors, such as lithology and prevailing conditions during formation, water availability in the aquifer and its rate of circulation, the activity of microorganisms, and temperature and pressure affect both the physical and chemical characteristics of groundwater (Ramanathan, 2004).

Groundwater usually contains dissolved mineral ions which can affect the water's usage depending on the type and concentrations of the ions involved (Okagbue, 1988; Boyle, 1988). Major cations and anions found in groundwater include $\mathrm{Ca}^{2+}, \mathrm{Mg}^{2+}, \mathrm{Na}^{+}, \mathrm{K}^{+}, \mathrm{HCO}_{3}{ }^{-}, \mathrm{SO}_{4}{ }^{2-}$ and $\mathrm{Cl}^{-}$. Non-ionic constituents such as oxides, phenols, synthetic detergents, dissolved $\mathrm{O}_{2}$ and $\mathrm{CO}_{2}$ are also found in groundwater (Tijani, 1994). These constituents determine the quality of ground water; and, if they are present in excessive amounts, the water may need to be treated before use (Tijani, 1994).

The inhabitants of Ngbo and the surrounding area are mostly farmers, traders and skilled craftsmen. These economic activities attract people to the area, and thus further increase the demand for potable water even as clean sources decline due to water pollution.

The major aim of this research is to investigate the infiltration of mineral ions into the groundwater of Ngbo community in Ohaukwu Area Council of Ebonyi State and thereafter compare results obtained with the standards set for water quality by the Nigerian Institute of Standards, the Bureau of Indian Standards and the World Health Organization.

\subsection{Description of study area}

Ohaukwu Area Council is one of the 13 Area Councils in Ebonyi State, South-East, Nigeria and it has three main communities namely Izhia, Ngbo and Effium. According to the 2006 population figures, Ohaukwu Council Area has an estimated population of 196,000 (NPC, 2006). The area lies within latitudes $6^{0} 3^{\prime} \mathrm{N}$ to $6^{0} 50^{\prime} \mathrm{N}$ and longitudes $7^{\circ} 80^{\prime} \mathrm{E}$ to $8^{0} 00^{\prime} \mathrm{E}$ with climatic conditions such as rainy season (March-October) and dry season (October-February). Two distinct vegetative regions exist in the study area: the Savannah in the Northern part of the study area, and tropical rainforests in the southern parts. More than $70 \%$ of the inhabitants of Ngbo engage in economic activities such as subsistent agriculture, petty trading, hunting and fishing (A.C. Umeji, Personal Communication, 2005).

Figure 1 shows a map of the study area with the sample locations identified.

\subsection{Geology of study site}

The bedrock in the study area is the Abakaliki Shale Formation, which is part of the Albian Asu River Group (99.6 - 112Ma). The area is mainly characterized by bedded shale with occasional sandy, splintery metamorphosed mudstone; lenses of sandstone and sandy limestone are highly jointed and fractured. (A.C. Umeji, Personal communication, 2005). The influence of tectonic activities introduced the discordant dip between the Asu River Group and the overlying Turonian Eze-Aku formation (Afikpo basin). Younger intrusive bodies, in combination with numerous faults and joint systems, have created secondary porosity in the shale. (A.C. Umeji, Personal communication, 2005). The fracture system spread across the Abakaliki anticlinorium and the Afikpo syncline in the Benue rift during the deformational 
episode originated from the vertical movement associated with the rising and cooling of magma, which intruded into the sediments in the sanitonian stage (A. C. Umeji, Personal communication, 2005). Sedimentary rock is folded and fractured, particularly south of Abakaliki, and the fold axes and dominant rock fractures are oriented northwest-southeast. The aquifer in the study area is formed by weathered rocks, alluvium and fractured zones, some of which are isolated.

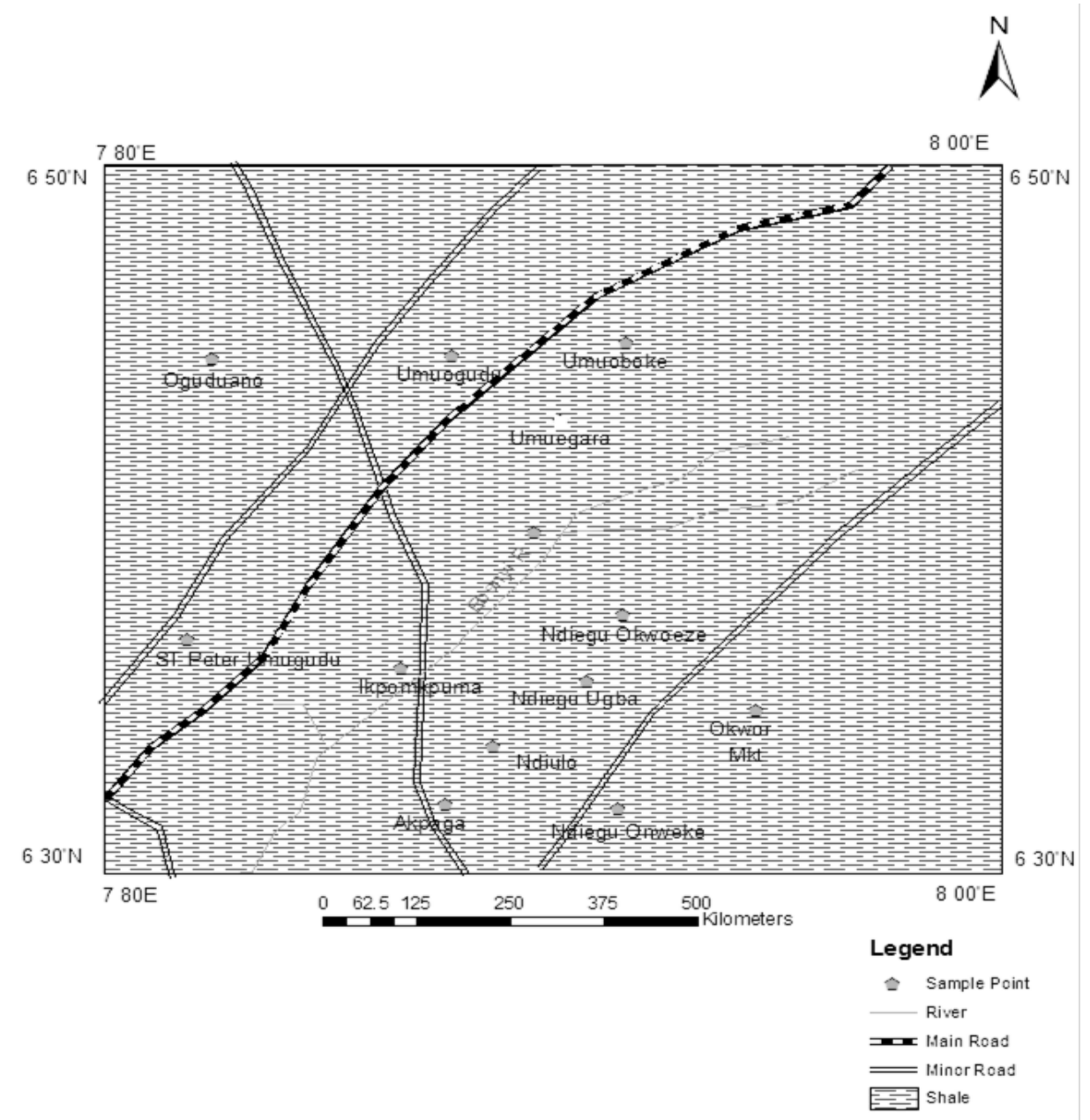

Figure 1. Map of the study area showing sampling locations.

\section{MATERIALS AND METHODS}

\subsection{Sampling}

Groundwater samples were collected at various locations within the study area from 11 boreholes during the dry season (February-March, 2013) at depths less than 40m $(<132 \mathrm{ft})$. Sampling was done in the dry season under good weather conditions in order to avoid rain water contamination which would have affected the quality of the rain water samples. Sample bottles were pre-cleaned before sampling by soaking them in 1:1 dilute $\mathrm{HCl}$ solution for 24 hours, and were later rinsed about 3 times with distilled water and further rinsed with the borehole water to be sampled in each case (Omaka, 2010). Sampling was done using two sets of pre-labelled one-liter polyethylene bottles for cation and anion analysis. Each pair of water samples was collected near the well head of each of the 11 sample boreholes by filling the sample bottle to the brim before corking it to ensure that dissolved $\mathrm{CO}_{2}$ was retained and also to minimize $\mathrm{O}_{2}$ contamination (Hem, 1985). Water samples for the determination of cations were stabilized by adding a few drops of dil. $\mathrm{HCl}$ after collection. To maintain the integrity of 
the water samples, physiochemical parameters sensitive to environmental changes such as $\mathrm{pH}$, conductivity and temperature were measured and recorded in-situ using portable digital meters. The samples were later transported to the laboratory in an ice chest for further analysis.

\subsection{Laboratory analyses}

The collected samples were analyzed for physicochemical properties $[\mathrm{pH}$, electrical conductivity (EC), turbidity, total dissolved solids (TDS), total hardness, chemical oxygen demand], cations $\left(\mathrm{Ca}^{2+}, \mathrm{Mg}^{2+}\right)$, anions $\left(\mathrm{SO}_{4}{ }^{2-}, \mathrm{Cl}^{-}, \mathrm{NO}_{3}{ }^{-}, \mathrm{PO}_{4}{ }^{3-}\right)$ and trace metals $(\mathrm{As}, \mathrm{Cu}, \mathrm{Ni}$, $\mathrm{Fe}, \mathrm{Pb}, \mathrm{Zn}, \mathrm{Cr}, \mathrm{Cd}, \mathrm{Mn}$ ) using the American Public Health Association (APHA et al., 2012) and American Standard for Testing Materials (ASTM, 2012) standard procedures (Table 1).

Table 1. Summary of analytical methods used for the analyses of groundwater samples.

\begin{tabular}{ll}
\hline Parameter measured & Standard Analytical Method used \\
\hline $\mathrm{pH}$ & ASTM D1293-12 \\
Temperature & APHA 2550 \\
Conductivity & APHA 2510B \\
$\mathrm{Ca}^{2+}, \mathrm{Mg}^{2+}$ & ASTM D511-09A \\
$\mathrm{As}^{2+}$ & D2972-08B \\
$\mathrm{Cu}^{2+}, \mathrm{Ni}^{2+}, \mathrm{Fe}^{2+}, \mathrm{Pb}^{2+}, \mathrm{Zn}^{2+}$, & ASTM D1688-07A, APHA 3113B, \\
$\mathrm{Cr}^{2+}, \mathrm{Cd}^{2+}, \mathrm{Mn}^{2+}$ & APHA, 3120B, ASTM D3559-08D, \\
$\mathrm{Total} \mathrm{dissolved} \mathrm{solids} \mathrm{(TDS)}^{2+}$ & APHA 3111B \\
$\mathrm{Total} \mathrm{hardness}^{2-}$ & APHA 2540C \\
$\mathrm{SO}_{4}{ }^{2-}$ & ASTM D4327-03 \\
$\mathrm{Cl}^{-}$ & ASTM D4327-03 \\
$\mathrm{NO}_{3}^{-}$ & ASTM D3867-90A \\
$\mathrm{PO}_{4}{ }^{3-}$ & ASTM D4327-03 \\
\hline
\end{tabular}

\subsection{Statistical analyses}

Relevant statistical packages (SPSS Version 17, Microsoft Excel 2009 Statistical Tool Pack) were used to analyze the data obtained and their levels of significance. Descriptive statistics, correlation analysis and one-way analysis of variance (ANOVA) were some of the analyses carried out in this study.

\section{RESULTS AND DISCUSSION}

A summary of the results of water chemistry (physico-chemical properties, cation and anion content and trace metal content) of the groundwater samples is presented in Tables 2 and 3 . 
Table 2. Hydrochemical parameters of water samples from various sampling points within Ngbo, Ebonyi State, Nigeria.

\begin{tabular}{|c|c|c|c|c|c|c|c|c|c|c|c|c|c|c|c|}
\hline $\mathbf{S} / \mathbf{N}$ & Sample location & Code & Temp & pH & DO & TDS & EC & TA & TH & $\mathbf{C a}$ & Mg & $\mathrm{Cl}$ & $\mathrm{SO}_{4}$ & $\mathrm{NO}_{3}$ & $\mathrm{PO}_{4}$ \\
\hline 1 & Ikpomkpuma & BH1 & 29 & 8.5 & 9.5 & 786 & 1754 & 640 & 172 & 31 & 141 & 167 & 48 & 0.62 & 0.10 \\
\hline 2 & Oguduanoo & $\mathrm{BH} 2$ & 29 & 8.2 & 8.6 & 188 & 432 & 164 & 89 & 35 & 55 & 82 & 27 & 0.74 & 0.19 \\
\hline 3 & Umuoboke & BH3 & 29 & 8.0 & 9.0 & 10 & 10 & 380 & 271 & 50 & 222 & 105 & 26 & 0.75 & 0.12 \\
\hline 4 & Akpegu & $3 \mathrm{H} 4$ & 29 & 8.2 & 9.2 & 388 & 753 & 310 & 202 & 21 & 181 & 112 & 21 & 0.76 & 0.10 \\
\hline 5 & Ndiegu Okwoeze & BH5 & 28 & 8.5 & 9.5 & 415 & 754 & 384 & 36 & 8 & 28 & 131 & 54 & 0.74 & 0.20 \\
\hline 6 & Ndiegu Ugba & BH6 & 29 & 8.3 & 9.4 & 213 & 495 & 190 & 177 & 31 & 147 & 150 & 42 & 0.74 & 0.23 \\
\hline 7 & St Peters Umuogudu & BH7 & 27 & 8.8 & 8.5 & 654 & 1240 & 476 & 41 & 25 & 16 & 136 & 36 & 0.50 & 0.14 \\
\hline 8 & Ndiulo & $3 \mathrm{H} 8$ & 29 & 8.4 & 9.5 & 397 & 857 & 327 & 76 & 25 & 51 & 70 & 63 & 0.47 & 0.15 \\
\hline 9 & Ndiegu Onweke & BH9 & 29 & 8.3 & 9.5 & 282 & 644 & 274 & 164 & 56 & 108 & 160 & 50 & 0.62 & 0.22 \\
\hline 10 & Okwor Market & BH10 & 27 & 8.7 & 9.5 & 338 & 922 & 296 & 140 & 30 & 110 & 147 & 63 & 0.73 & 0.23 \\
\hline 11 & Ebenyi River & BH11 & 28 & 7.8 & 4.0 & 35 & 42 & 15 & 14 & 35 & 10 & 42 & 21 & 0.62 & 0.24 \\
\hline
\end{tabular}

Note: DO-Dissolved oxygen, EC-Electrical conductivity, TDS-Total dissolved solids, TA-Total alkalinity, TH-Total hardness. All parameters have been expressed as $\mathrm{mg} / \mathrm{L}$ except $\mathbf{p H}$ and $\mathbf{E C}$. The unit of $\mathbf{E C}$ is $\mu \mathrm{S} / \mathrm{cm}$.

Table 3. Trace metal levels in groundwater samples from various locations within Ngbo, Ebonyi State.

\begin{tabular}{|c|c|c|c|c|c|c|c|c|c|c|}
\hline $\mathbf{S} / \mathbf{N}$ & Code & As & $\mathrm{Cu}$ & $\mathbf{N i}$ & $\mathbf{F e}$ & $\mathbf{P b}$ & $\mathbf{Z n}$ & $\mathrm{Cr}$ & Cd & Mn \\
\hline 1 & BH1 & 0.44 & 0.024 & 0.014 & 0.424 & 0.058 & 0.004 & BDL & BDL & 0.125 \\
\hline 2 & $\mathrm{BH} 2$ & 0.90 & 0.056 & 0.020 & 2.890 & BDL & 0.173 & BDL & BDL & 0.330 \\
\hline 3 & BH3 & 0.90 & 0.100 & 0.015 & 0.452 & BDL & 0.012 & 0.040 & BDL & 0.167 \\
\hline 4 & BH4 & 0.41 & 0.130 & 0.009 & 0.362 & BDL & 0.007 & 0.088 & 0.002 & 0.030 \\
\hline 5 & BH5 & 0.95 & 0.024 & 0.008 & 0.438 & BDL & 0.003 & 0.064 & BDL & BDL \\
\hline 6 & BH6 & 0.61 & 0.016 & 0.012 & 0.435 & BDL & 0.004 & BDL & BDL & 0.294 \\
\hline 7 & BH7 & 0.41 & 0.033 & 0,012 & 0.455 & BDL & 0.004 & BDL & BDL & BDL \\
\hline 8 & BH8 & 0.47 & 0.023 & 0.011 & 0.543 & BDL & 0.003 & 0.024 & BDL & 0.027 \\
\hline 9 & BH9 & 0.73 & 0.158 & 0.011 & 1.772 & BDL & 0.256 & BDL & BDL & 0.122 \\
\hline 10 & BH10 & 1.20 & 0.026 & 0.010 & 0.545 & BDL & 0.004 & BDL & BDL & 0.221 \\
\hline 11 & BH11 & 0.35 & 0.030 & 0.010 & 0.400 & 0.030 & 0.020 & BDL & BDL & 0.100 \\
\hline
\end{tabular}

Note: BDL-Below detection limit. Concentration of trace metals are given in parts per million (ppm). 
Table 4 gives the descriptive statistics of the data generated showing the minimum, maximum, mean, standard deviation and variance values of various parameters investigated in this study compared with national and global drinking water standards such as the Nigerian Institute of Standards (NIS) (SON, 2007), the Bureau of Indian Standards (BIS) (India, 2006) and the World Health Organization (WHO) water standards for drinking and public health purposes.

The temperature of the water samples ranged from $27-29^{\circ} \mathrm{C}$ with a mean temperature of $28.45^{\circ} \mathrm{C}$, which compares favorably with mean atmospheric temperature $\left(28^{\mathrm{O}} \mathrm{C}\right)$, thus suggesting the influence of local climatic conditions. For the $\mathrm{pH}$, values ranged from 7.8-8.8 with a mean of 8.34, which is within the WHO-stipulated tolerable range of 6.5-.8.5 for potable water (WHO, 2011). This shows that majority of the groundwater samples were mildly alkaline, which can be traced to the nature of weathered rocks and aquifers found within the Ngbo area of Ebonyi State. However, the observed $\mathrm{pH}$ range (7.8-8.8) in this study was higher than the $\mathrm{pH}$ ranges of 3.84-7.72 and 5.8-6.9 recorded for groundwater in parts of the eastern Niger Delta (Nwankwoala and Udom, 2011) and parts of Bayelsa State (Okiongbo and Douglas, 2013), respectively. On the other hand, the recorded $\mathrm{pH}$ range (7.8-8.8) of groundwater samples in this study is lower than that (8.3-9.6) obtained for groundwater in Ekiti State by Talabi and Tijani in 2010.

The mean EC and TDS values of the groundwater samples were $718.45 \mu \mathrm{S} / \mathrm{cm}$ and $336.91 \mathrm{mg} / \mathrm{L}$ as compared to the WHO maximum standards of $1250 \mu \mathrm{S} / \mathrm{cm}$ and $1200 \mathrm{mg} / \mathrm{L}$, respectively, for potable water (WHO, 2011). The relatively high EC value suggests the presence of highly mineralized freshwater in Ngbo area of Ebonyi State. Electrical conductivity is a measure of salinity, which can affect the taste of water and hence its suitability as drinking water source (Langenegger, 1990). The maximum allowable EC limit for groundwater is $1400 \mu \mathrm{S} / \mathrm{cm}$ which, if exceeded, renders such water unsuitable for irrigation (Ragunath, 1987). Except for the borehole at Ikpomkpuma (BH1), with an EC value of $1754 \mu \mathrm{S} / \mathrm{cm}$ which exceeded the $1400 \mu \mathrm{S} / \mathrm{cm}$ limit, all other boreholes investigated produced water suitable for irrigation.

The total alkalinity (TA) of the groundwater samples ranged from $15 \mathrm{mg} / \mathrm{L}$ to $640 \mathrm{mg} / \mathrm{L}$ with a mean value of $314.18 \mathrm{mg} / \mathrm{L}$, showing that all the TA values were within the maximum allowable limit $(600 \mathrm{mg} / \mathrm{L})$ set by ISI, except for BH1(640 mg/L). Thus, except for BH1, all other boreholes investigated contain water that is suitable for drinking or domestic use. Excessive amounts of calcium in the form of calcium carbonates form temporary hardness in water, while the presence of sulphates, nitrates and chlorides tend to form permanent hardness in water (Twort et al., 2000). The groundwater samples can be classified into different water categories based on their total hardness $(\mathrm{TH})$ values as follows: 3 boreholes (BH5, BH7, BH11) fall into the soft water category $(<75 \mathrm{mg} / \mathrm{L} \mathrm{TH}), 2$ boreholes $(\mathrm{BH} 2, \mathrm{BH} 8)$ fall into the moderate water category $(75-150 \mathrm{mg} / \mathrm{L})$ while 6 boreholes $(\mathrm{BH} 1, \mathrm{BH} 3, \mathrm{BH} 4, \mathrm{BH} 6, \mathrm{BH} 9$, BH10) fall into the hard water category $(150-300 \mathrm{mg} / \mathrm{L} \mathrm{TH})$.

The mean Ca content $(28.68 \mathrm{mg} / \mathrm{L})$ of water samples was lower than the WHO-stipulated standard $(75 \mathrm{mg} / \mathrm{L})$ for $\mathrm{Ca}$ in potable water (WHO, 2011). Similarly, the mean $\mathrm{Mg}$ content $(97.18 \mathrm{mg} / \mathrm{L})$ of water samples was also higher than the WHO stipulated standard $(50 \mathrm{mg} / \mathrm{L})$ for $\mathrm{Mg}$ in potable water (WHO, 2011). Chloride concentrations in the groundwater samples ranged from $42-167 \mathrm{mg} / \mathrm{L}$, with a mean value of $118.36 \mathrm{mg} / \mathrm{L}$, which is below the WHO standard $(250 \mathrm{mg} / \mathrm{L})$ for $\mathrm{Cl}^{-}$in potable water (WHO, 2011). Sulphate concentrations in the groundwater samples ranged from $21-63 \mathrm{mg} / \mathrm{L}$, with a mean value of $41 \mathrm{mg} / \mathrm{L}$, which is below the WHO maximum limit $(500 \mathrm{mg} / \mathrm{L})$ for $\mathrm{SO}_{4}{ }^{2-}$ in potable water (WHO, 2011). The low values recorded for $\mathrm{SO}_{4}{ }^{2-}$ in these water samples could be due to its removal from the water by bacteria (Freeze and Cherry, 1979). Nitrate concentrations in the water samples ranged from $0.47-0.76 \mathrm{mg} / \mathrm{L}$, with a mean value of $0.66 \mathrm{mg} / \mathrm{L}$, which is well below the WHO 
standard $(50 \mathrm{mg} / \mathrm{L})$ for $\mathrm{NO}_{3}{ }^{-}$in domestic/public water supply (WHO, 2011). The major percentage of nitrogen found in groundwater is gotten from the biosphere (Saleh et al., 1999). The cycle for formation of nitrate in nature begins with nitrogen fixation in the atmosphere with mineralization into ammonia by soil bacteria, followed by the conversion of nitrogen into nitrate by nitrifying bacteria under aerobic conditions (Tindall et al., 1995). Toxic effects of high concentrations of nitrate in drinking water include blue baby disease in children and gastric carcinomas (Gilly et al., 1984).

Trace metal levels in the groundwater samples were in minute quantities when compared to major cations and anions. Cadmium had the least mean concentration $(0.000182 \mathrm{mg} / \mathrm{L})$ while Fe had the highest mean concentration $(0.792 \mathrm{mg} / \mathrm{L})$. The noticeably high concentration of $\mathrm{Fe}$ in groundwater samples throughout the study area can be attributed to factors influencing iron solubility and concentration in ground water (Okiongbo and Douglas, 2013).The relative abundance of the trace metals arranged in increasing order of magnitude is as follows: $\mathrm{Cd}<\mathrm{Pb}<\mathrm{Ni}<\mathrm{Cr}<\mathrm{Zn}<\mathrm{Cu}<\mathrm{Mn}<\mathrm{As}<\mathrm{Fe}$.

Schoeller diagram depicting logarithmic data plots for the major ions investigated is shown in Figure 2. The peaks and troughs of the individual water samples indicate their dominant and less dominant ions respectively. A look at Figure 2 shows that $\mathrm{Mg}^{2+}$ is the most dominant ion followed by $\mathrm{Cl}^{-}$and $\mathrm{Ca}^{2+}$ in that order whereas $\mathrm{NO}_{3}{ }^{-}$and $\mathrm{PO}_{4}{ }^{3-}$ are the least dominant ions.

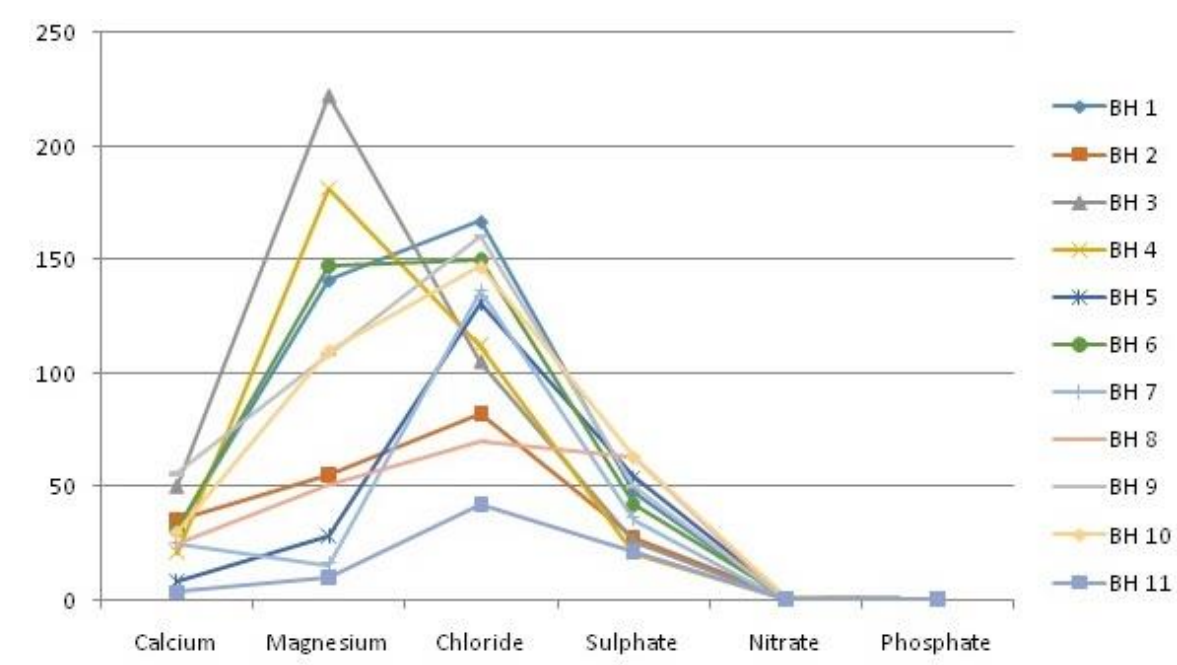

Figure 2. Schoeller Diagram of the major ionic species investigated.

A Pearson correlation analysis of the data generated (Table 5) was done using Microsoft EXCEL 2007 Statistical Tool Package. Positive correlations existed between the following parameters: Temp- $\mathrm{NO}_{3}$ (0.183), Temp-Mg (0.504), Temp-Ca (0.398), Temp-TH (0.517), Temp-DO (0.224), pH-DO (0.6), pH-TDS (0.906), pH-EC (0.788), pH-TA (0.625),

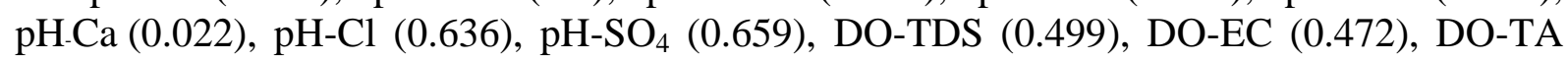
(0.601), DO-TH (0.484), DO-Ca (0.511), DO-Mg (0.442), DO-Cl (0.679), DO-SO 4 (0.55), $\mathrm{DO}_{-\mathrm{NO}_{3}}(0.147)$, TDS-EC (0.81), TDS-TA (0.584), TDS-Cl (0.528), TDS-SO 4 (0.583), EC-TA (0.791), EC-Cl (0.599), EC-SO $_{4}$ (0.494), TA-TH (0.26), TA-Ca (0.207), TA-Mg (0.25), TA-Cl (0.61), TA-SO 4 (0.343), TH-Ca (0.7), TH-Mg (0.988), TH-Cl (0.405), $\mathrm{TH}_{-} \mathrm{NO}_{3}$ (0.474), Ca-Mg (0.581), Ca-Cl (0.429), Ca- $\mathrm{SO}_{4}$ (0.086), Ca- $\mathrm{NO}_{3}$ (0.086), $\mathrm{Mg}-\mathrm{Cl}(0.367), \mathrm{Mg}-\mathrm{NO}_{3}(0.524), \mathrm{Cl}-\mathrm{SO}_{4}(0.433), \mathrm{Cl}-\mathrm{NO}_{3}(0.158), \mathrm{SO}_{4}-\mathrm{PO}_{4}(0.223), \mathrm{NO}_{3}-\mathrm{PO}_{4}$ (0.141). This trend suggests that the pairs of concerned ions originated from common natural and anthropogenic sources. 
Table 4. Descriptive statistics of analyzed groundwater samples compared with NIS, ISI and WHO Standards for Drinking Water Quality.

\begin{tabular}{|c|c|c|c|c|c|c|c|}
\hline Parameter & Minimum & Maximum & Mean & $\begin{array}{l}\text { Standard } \\
\text { deviation }\end{array}$ & NIS: 2007 & $\begin{array}{c}\text { BIS: } \\
105001991\end{array}$ & WHO:2011 \\
\hline Temp. $\left({ }^{\circ} \mathrm{C}\right)$ & 27 & 29 & 28.45 & 0.820 & Ambient & - & - \\
\hline $\mathrm{pH}$ & 7.8 & 8.8 & 8.34 & 0.291 & $6.5-8.5$ & $6.5-8.5$ & $6.5-8.5$ \\
\hline $\mathrm{DO}(\mathrm{mg} / \mathrm{L})$ & 4 & 9.5 & 8.75 & 1.617 & - & - & 4 \\
\hline TDS (mg/L) & 10 & 786 & 336.91 & 235.183 & 500 & 500 & 1200 \\
\hline $\mathrm{EC}(\mu \mathrm{S} / \mathrm{cm})$ & 10 & 1754 & 718.45 & 500.448 & 1000 & - & 1250 \\
\hline $\mathrm{TA}(\mathrm{mg} / \mathrm{L})$ & 15 & 640 & 314.18 & 164.670 & - & 200 & - \\
\hline TH (mg/L) & 14 & 271 & 125.64 & 80.557 & 150 & 300 & - \\
\hline $\mathrm{Ca}^{2+}(\mathrm{mg} / \mathrm{L})$ & 3.5 & 56 & 28.68 & 15.496 & - & 75 & 75 \\
\hline $\mathrm{Mg}^{2+}(\mathrm{mg} / \mathrm{L})$ & 10 & 222 & 97.18 & 70.836 & 0.2 & 30 & 50 \\
\hline $\mathrm{Cl}^{-}(\mathrm{mg} / \mathrm{L})$ & 42 & 167 & 118.36 & 40.128 & 250 & 250 & 250 \\
\hline $\mathrm{SO}_{4}{ }^{2-}(\mathrm{mg} / \mathrm{L})$ & 21 & 63 & 41.00 & 15.856 & 100 & 150 & 500 \\
\hline $\mathrm{NO}_{3}^{-}(\mathrm{mg} / \mathrm{L})$ & 0.47 & 0.76 & 0.66 & 0.104 & 50 & 45 & 50 \\
\hline $\mathrm{PO}_{4}{ }^{3-}(\mathrm{mg} / \mathrm{L})$ & 0.10 & 0.24 & 0.18 & 0.054 & - & - & 10 \\
\hline As (mg/L) & 0.35 & 1.20 & 0.67 & 0.283 & 0.01 & 0.05 & - \\
\hline $\mathrm{Cu}(\mathrm{mg} / \mathrm{L})$ & 0.016 & 0.158 & 0.056 & 0.0497 & 1 & 0.05 & - \\
\hline $\mathrm{Ni}(\mathrm{mg} / \mathrm{L})$ & 0.008 & 0.020 & 0.012 & 0.00335 & 0.02 & - & - \\
\hline $\mathrm{Fe}(\mathrm{mg} / \mathrm{L})$ & 0.362 & 2.890 & 0.792 & 0.803 & 0.3 & 0.3 & 0.3 \\
\hline $\mathrm{Pb}(\mathrm{mg} / \mathrm{L})$ & 0.00 & 0.058 & 0.008 & 0.0189 & 0.01 & 0.05 & - \\
\hline $\mathrm{Zn}(\mathrm{mg} / \mathrm{L})$ & 0.003 & 0.256 & 0.0445 & 0.0862 & 3 & 5 & - \\
\hline $\mathrm{Cr}^{6+}(\mathrm{mg} / \mathrm{L})$ & 0.000 & 0.088 & 0.0196 & 0.0313 & 0.05 & 0.05 & - \\
\hline $\mathrm{Cd}(\mathrm{mg} / \mathrm{L})$ & 0.000 & 0.002 & 0.000182 & 0.000603 & 0.003 & 0.01 & - \\
\hline $\mathrm{Mn}(\mathrm{mg} / \mathrm{L})$ & 0.000 & 0.330 & 0.129 & 0.115 & 0.200 & 0.1 & 0.1 \\
\hline
\end{tabular}

Note: DO-dissolved oxygen, TDS-total dissolved solids, EC-electrical conductivity, TA-total alkalinity, TH-total hardness as $\mathrm{CaCO}_{3}$.

On the other hand, negative correlations existed among the following pairs of parameters: Temp-pH (-0.537), Temp-TDS (-0.462), Temp-EC (-0.197), Temp-TA (-0.043), Temp-Cl (-0.088), Temp-SO $\mathrm{S}_{4}$ (-0.208), Temp- $\mathrm{PO}_{4}$ (-0.299), $\mathrm{pH}-\mathrm{TH}(-0.179), \mathrm{pH}-\mathrm{Mg}(-0.21)$,

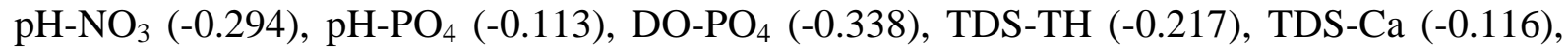

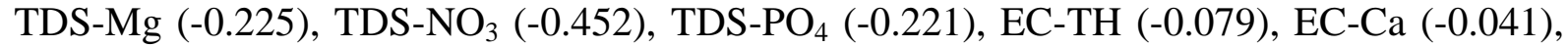
EC-Mg (-0.084), EC-NO (-0.393), EC-PO $_{4}(-0.424)$, TA-NO ${ }_{3}(-0.23)$, TA-PO 4 (-0.71), TH.SO 4 (-0.14), TH-PO 4 (-0.41), Ca-PO (-0.14), $\mathrm{Mg}_{-} \mathrm{SO}_{4}$ (-0.18), $\mathrm{Mg}_{-} \mathrm{PO}_{4}(-0.43), \mathrm{Cl}-\mathrm{PO}_{4}$ $(-0.09), \mathrm{SO}_{4}-\mathrm{NO}_{3}(-0.3)$. This trend infers that the pairs of concerned ions involved came from different natural and anthropogenic sources.

One-way analysis of variance (ANOVA) tests were conducted to determine whether significant differences existed between the physico-chemical parameters, cations/anions and trace metals data generated during this study. In the case of physico-chemical parameters, the ANOVA test at $\mathrm{P}=0.05$ shows that $\mathrm{F}=1.004<\mathrm{Fcrit}=1.977$, implying that no significant differences exist between the physico-chemical parameters in the groundwater samples, irrespective of the sampling location. Similarly, subjecting the data generated from determination of major cations and anions in the groundwater samples to the ANOVA test at 
$\mathrm{P}=0.05$ shows that $\mathrm{F}=0.547<\mathrm{Fcrit}=2.008$, implying that no significant differences exist in the results, irrespective of sampling location. Further, with regard to trace metals, subjecting the data generated to the ANOVA test at $\mathrm{P}=0.05$ shows that $\mathrm{F}=0.772<\mathrm{Fcrit}=1.940$, suggesting that no significant differences exist in the results, regardless of borehole location.

Table 5. Pearson correlation coefficient matrix of measured parameters in groundwater samples.

\begin{tabular}{|c|c|c|c|c|c|c|c|c|c|c|c|c|c|}
\hline & Temp & pH & DO & TDS & EC & TA & TH & $\mathrm{Ca}^{2+}$ & $\mathbf{M g}^{2+}$ & $\mathrm{Cl}^{-}$ & $\mathrm{SO}_{4}{ }^{2-}$ & $\mathrm{NO}_{3}{ }^{-}$ & $\mathrm{PO}_{4}{ }^{3-}$ \\
\hline Temp & 1 & & & & & & & & & & & & \\
\hline $\mathrm{pH}$ & -0.537 & 1 & & & & & & & & & & & \\
\hline DO & 0.224 & 0.600 & 1 & & & & & & & & & & \\
\hline TDS & -0.462 & 0.906 & 0.4991 & 1 & & & & & & & & & \\
\hline EC & -0.197 & 0.788 & 0.4724 & 0.810 & 1 & & & & & & & & \\
\hline TA & -0.043 & 0.625 & 0.6007 & 0.584 & 0.791 & 1 & & & & & & & \\
\hline $\mathrm{TH}$ & 0.517 & -0.179 & 0.4843 & -0.217 & -0.079 & 0.260 & 1 & & & & & & \\
\hline $\mathrm{Ca}^{2+}$ & 0.398 & 0.022 & 0.5105 & -0.116 & -0.041 & 0.207 & 0.700 & 1 & & & & & \\
\hline $\mathrm{Mg}^{2+}$ & 0.504 & -0.21 & 0.4419 & -0.225 & -0.084 & 0.250 & 0.988 & 0.581 & 1 & & & & \\
\hline $\mathrm{Cl}^{-}$ & -0.088 & 0.636 & 0.6789 & 0.528 & 0.599 & 0.610 & 0.405 & 0.429 & 0.367 & 1 & & & \\
\hline $\mathrm{SO}_{4}{ }^{2-}$ & -0.208 & 0.659 & 0.5500 & 0.583 & 0.494 & 0.343 & -0.140 & 0.086 & -0.180 & 0.433 & 1 & & \\
\hline $\mathrm{NO}_{3}^{-}$ & 0.183 & -0.294 & 0.1469 & -0.452 & -0.393 & -0.230 & 0.474 & 0.086 & 0.524 & 0.158 & -0.300 & 1 & \\
\hline $\mathrm{PO}_{4}^{3-}$ & -0.299 & -0.113 & -0.338 & -0.221 & -0.424 & -0.710 & -0.410 & -0.140 & -0.430 & -0.090 & 0.223 & 0.1412 & 1 \\
\hline
\end{tabular}

\section{CONCLUSION}

Hydrochemical analyses revealed that the groundwater within Ngbo area of Ebonyi State and its environs is slightly alkaline, but mostly hard in nature and highly mineralized. All of the parameters investigated in this study fall within national (NIS, BIS) and international (WHO) standards for potable water except for total alkalinity, $\mathrm{Mg}, \mathrm{As}, \mathrm{Cu}$ and Fe levels in the samples. Magnesium and iron values were exceptionally high in some of the groundwater samples studied and a possible treatment procedure involves the periodic exposure of the water samples to air in order to allow the concerned ions to precipitate. Precipitates formed may then be filtered out to obtain potable water. Further, the slightly high average electrical conductivity $(718.45 \mu \mathrm{S} / \mathrm{cm})$ of the water samples implies that some of them are saline rather than fresh in nature. This implies that all the groundwater samples are suitable for irrigation purposes, though not all of them are suitable as a source of drinking water. Also, slightly high total dissolved solids and chloride concentrations imply possible encroachment of saltwater into the groundwater. To mitigate this challenge, regular flushing of boreholes is recommended in order to aid in the removal of mineralized deposits accumulated in the groundwater over time. In conclusion, there is a need for regular hydrogeochemical studies in the study area in order to detect any future deterioration of groundwater quality.

\section{REFERENCES}

ABAM, T. K. S. Regional hydrological research perspective in the Niger Delta. Hydrological Sciences Journal, v. 46, n. 1, 2001. http://dx.doi.org/10.1080/02626660109492797 
ACHI, C. Hydrocarbon exploitation, Environmental degradation and Poverty: The Niger Delta Experience. In: ENVIRONMENTAL POLLUTION CONFERENCE, 2003, Dublin. Proceedings... Dublin: [s.n.], 2003. p. 78-94.

AKUJIEZE, C. N.; COKER, S. J. L.; OTEZE, G. E. Groundwater in Nigeria-A millennium experience: distribution, practice, problems and solutions. Hydrogeology Journal, v. 11, n. 2, p. 259-274, 2003. http://dx.doi.org/10.1007/s10040-002-0227-3

AMADI, A. N.; OLASEHINDE, P. I.; YISA, J.; OKOSUN, E. A.; NWANKWOALA, H. O.; ALKALI, Y. B. Geostatistical assessment of groundwater quality of coastal aquifers of Eastern Niger Delta. Geosciences, v. 2, n. 3, p. 51-59, 2012. http://dx.doi.org/10.5923/j.geo.20120203.03

AMERICAN PUBLIC HEALTH ASSOCIATION - APHA; AMERICAN WATER WORKS ASSOCIATION - AWWA; WATER POLLUTION CONTROL FEDERATION WPCF. Standard methods for the examination of water and waste water. $22^{\text {th }}$ ed. Washington DC, 2012.

AMERICAN SOCIETY TESTING MATERIALS - ASTM Annual Book of ASTM Standards. 2012. Vol. 11.01. Available in: http://www.astm.org. Access in: Oct. 2014.

BOYLE, D. R. Application of groundwater geochemistry in mineral exploration. In: BERRY, M. J. (Ed.). Proceedings of Current Activities Forum. Dartmouth: Geological Survey of Canada, 1988.

FREEZE, R. A.; CHERRY, J. A. Groundwater. Englewood Cliffs: Prentice-Hall, 1979.

GILLY, G.; CORRAO, G.; FAVILLI, S. Concentrations of nitrates in drinking water and incidence of gastric carcinomas: First descriptive study of the Piemonate Region, Italy. Science of the Total Environment, v. 34, p. 35-37, 1984.

HANIDU, J. A. National growth, water demand and supply strategies in Nigeria in the 1990s. Water Resource Journal of Nigerian Association of Hydrogeologists, V. 2, n. 1, p. $1-6,1990$.

HEM, J. D. Study and interpretation of the chemical characteristics of natural water. Water Supply Paper, n. 2254, 1985. (Technical Paper n. 2254)

INDIA. Public Health Engineering Department. Bureau of Indian Standard. Specification for Drinking Water (BIS: 105001991). West Bengal, 2006.

LANGENEGGAR, O. Groundwater quality in rural areas of Western Africa. UNDPProject INT/81/026. Abdijan: World Bank; Regional Water and Sanitation Group, 1990. p.10

NATIONAL POPULATION COMMISSION - NPC. National Population and Housing Census. [S.I.], 2006.

STANDARDS ORGANIZATION OF NIGERIA - SON. Nigerian Standard for Drinking Water Quality: Nigerian Industrial Standard (NIS: 554). [S.1.], 2007. p. 30.

NWANKWOALA, H. O.; OKEKE E. V.; OKEREKE S. C. Groundwater quality in parts of Port-Harcourt, Nigeria: an overview, trends and concerns. International Journal of Biotechnology and Allied Sciences, v. 2, n. 3, p. 282-289, 2007. 
NWANKWOALA, H. O.; UDOM, G. J. Investigation of hydrogeochemical characteristics of groundwater in Port- Harcourt City, Nigeria: implication for use and vulnerability. Journal of Applied Science and Environmental Management, v. 15, n. 3, p. 479488, 2011.

OBATOYINBO, O.; OYEDOTUN, T. D. T. Microbial/bacteriological analysis of water resources in Ikare and Arigidi Akoko of Ondo state, Nigeria. In: EIT INTERNATIONAL CONFERENCE ON WATER RESOURCES ENGINEERING, 18 19 August, Cha-Am. Proceedings... [S.l.: s.n.], 2011. Vol. 1. p. 279-284.

OKAGBUE, C. O. Hydrology and chemical characteristics of surface and groundwater resources of the Okigwe area and environs, Imo State, Nigeria. In: OFOEGBU, C. O. (Ed.). Groundwater and mineral resources of Nigeria. Braunschweig: Vieweg and Sohn, 1988. p. 3-16.

OKIONGBO, K. S.; DOUGLAS, R. Hydrogeochemical analysis and evaluation of groundwater quality in Yenagoa City and Environs, Southern Nigeria. Ife Journal of Science, v. 15, n. 2, p. 209-222, 2013.

OlATUNJI, A. S.; ABIMBOlA, A. F.; OlORUNTOLA, M. O.; ODEWADE, A. A. Hydrogeochemical evaluation of groundwater resources in shallow coastal aquifers around Ikorodu area, Southwestern Nigeria. Water Resources, v. 16, p. 65-71, 2005.

OMAKA O. N. Atmospheric and Metallic Pollutants and their impacts on the Environment: Case Study of Abakaliki Metropolis. Journal of Applied and Natural Sciences (JANS), v. 4, n. 1, p. 24-29, 2010.

OYEDOTUN, T. D. T.; OBATOYINBO, O. Hydrogeochemical evaluation of groundwater quality in Akoko North West Local Government Area of Ondo State, Nigeria. Revista Ambiente \& Água, Taubaté, v. 7, n. 1, p. 67-80, 2012. http://dx.doi.org/10.4136/ambiagua. 851

RAGUNATH, H. M. Groundwater. New Delhi: Wiley Eastern, 1987. p. 563.

RAMANATHAN, A. L. Water quality: guidelines and assessment of risk. New Delhi: School of Environmental Sciences, 2004. p. 110-167.

RIJSWIJK, K. Small community water supplies. The Hague: IRC, 1981 (Technical paper 18).

SALEH, A.; AL-RUWATH, F.; SHEHATA, M. Hydrogeochemical processes operating within the main aquifers of Kuwait. Journal of Arid Environment, v. 42, p. 195-209, 1999. http://dx.doi.org/10.1006/jare.1999.0511

TALABI A. O.; TIJANI, M. N. Assessment of groundwater quality in parts of the basement complex terrain of Southwestern Nigeria. GQ10: Groundwater quality management in a rapidly changing world. In: INTERNATIONAL GROUNDWATER QUALITY CONFERENCE, 7., 13-18 June 2010, Zurich. Proceedings...Zurich: IAHS, 2011. p. 503-506. (IAHS Publication, 342).

TIJANI, M. N. Hydrogeochemical assessment of groundwater in Moro are, Kwara State, Nigeria. Environmental Geology, v. 24, n. 3, p. 194-202, 1994. http://dx.doi.org/10.1007/BF00766889

TINDALL, J. A.; PETRUSAK, R. L.; MCMOHAN, P. B. Nitrate transport and transportation process in unsaturated porous media. Journal of Hydrology, v. 169, p. 51-94, 1995. 
TWORT, A. C.; RATNAYAKA, D. D.; BRADT M. J. Water Supply. $5^{\text {th }}$ ed. London: Arnold and IWA Publishing, 2000.

WORLD HEALTH ORGANIZATION - WHO Guidelines for drinking water quality criteria. $4^{\text {th }}$ ed. Geneva, 2011. p. 307-441. 